\title{
POLITICAL DISCOURSE IN POST-DIGITAL SOCIETIES
}

\section{O DISCURSO POLITITCO EM SOCIEDADES PÓS-DIGITAIS}

\author{
Jan Blommaert ${ }^{\star, *}$
}

\begin{abstract}
In his contribution to the Special Issue "Digital and semiotic mechanisms of contemporary populisms", Jan Blommaert offers a communicability model which accounts for political discourse (and others) in the post-digital era we live. He starts by arguing that the idea of the public (a homogeneous entity) that was very popular in the $20^{\text {th }}$ century sociological imagination of how propaganda worked in "manufacturing consent" can no longer be used to explain the fragmented audiences of our post-digital era. The author illuminates his argument by resorting to the circulation of political tweets/retweets as texts in our algorithmic-oriented world. Such a circulation aims at niched audiences. In the last section, the author argues that discourse analysts need to operate from this communicability model if they are to understand the cruciality of political discourse in our contemporary social lives.
\end{abstract}

Keywords: political discourse; post-digital societies; propaganda; niched audiences; Twitter.

\section{RESUMO}

Em sua contribuição ao dossiê "Mecanismos digitais e semióticos dos populismos contemporâneos", Jan Blommaert oferece um modelo de comunicabilidade que aborda discursos políticos (e outros) na era pós-digital em que vivemos. Ele começa argumentando que a ideia do público (uma entidade homogênea) - muito popular na imaginação sociológica do século XX - como base para explicar como a propaganda "produzia consenso" não pode mais ser usada para explicar as audiências fragmentadas de nossa era pós-digital. $\mathrm{O}$ autor ilumina seu argumento ao se debruçar na circulação de tweets/retweets políticos como textos em nosso mundo orientado algoritmicamente. Tal circulação se direciona a audiências de nicho. Na última seção, o autor argumenta que analistas do discurso precisam operar com tal modelo de comunicabilidade se quiserem compreender o quão crucial o discurso político é em nossas vidas sociais contemporâneas.

Palavras-chave: discurso político; sociedades pós-digitais; propaganda; audiências de nicho; Twitter.

\footnotetext{
* Tilburg School of Humanities and Digital Sciences, Department of Culture Studies, Tilburg University, Netherlands.

** Babylon, Center for the Study of Superdiversity, Tilburg University, Netherlands. jmeblommaert@ gmail.com

ORCID: https://orcid.org/0000-0002-2474-953X
} 


\section{POINT OF DEPARTURE}

The point of departure for what follows is this observation. ${ }^{1}$ Since the beginning of the $21^{\text {st }}$ century, we live our social, cultural, political and economic lives in an online-offline nexus, in which both 'zones' - the online and the offline - can no longer be separated and must be seen as fused into a bewildering range of new online-offline practices of social interaction, knowledge exchange, learning, community formation and identity work. The so-called 'digital revolution' has already happened, it has become 'historical' according to Florian Cramer (2014), and we have entered a 'post-digital' era in which big-tech innovation is matched by grassroots searches for agency, DIY media creation and hybrid media systems.

This has profoundly affected the flows of information in societies such as ours, and we need to get our heads around these new ways in addressing their outcomes: messages, meanings and the social configurations within which they circulate. This evidently includes political messages and meanings. Note that such messages and meanings are almost without exception mediatized (and thus mediated) messages and meanings, reaching their audiences due to the mediating impact of media systems. For most people, political discourse is indirectly accessed through the specter of the media they are exposed to.

One can reformulate this general observation. Digital infrastructures have become part of what is conventionally described as 'social structure' - the deep, generic and often invisible drivers behind actual social conduct - and such infrastructures now demand much more attention in research on messages and meanings (cf. ARNAUT; KARREBAEK; SPOTTI, 2017). Concretely: not just the content should be central to discourse-analytic research, but systems of communication and the way in which they shape new sociolinguistic conditions for production, circulation and uptake of discourses, new resources, new actors and new relations between actors (MALY, 2018). Post-digital environments are new sociolinguistic environments and discourse analysis cannot avoid attention to the sociolinguistic conditions affecting contemporary discourses.

The point of departure has been sketched. I shall now offer three connected reflections on the analysis of political discourse within these postdigital conditions.

1. This essay is the written version of the opening statement of a Babylon webinar on this topic, held on 25 November 2019 and involving audiences from Brazil, Argentina and Australia. I am grateful to all participants for the very stimulating discussion we had during the webinar. 


\section{REVISITING PROPAGANDA MODELS}

Propaganda models are linear models of political mass communication, in which the messages and meanings of powerful actors - politicians in this case - are passed on to 'the public' by mass media owned or operated by actors sharing the same interests as those articulated by the powerful actors.

Mass media, in such models, act as an intensifying and expansive conduit for the interests of the powerful, and their monopoly in the public sphere ensures propaganda effects on 'public opinion'.

Various versions of propaganda models (the most widely known one is HERMAN, CHOMSKY, 1988) have been predominant in critical discussions of mass media and politics throughout the $20^{\text {th }}$ century ${ }^{2}$, and they informed much early and influential work in Critical Discourse Analysis as well (e.g. FAIRCLOUGH, 1989). These models are grounded in a modernist imagination of 'the public' (hence the scare quotes I put around this term) and the public sphere, in which 'the public' is usually seen as 'the masses'. The latter are amorphous and inert therefore vulnerable to propaganda - and coinciding with the statistical notion of 'population', which allowed it to be investigated by means of notions such as 'public opinion' and to be structured into averages, majorities and minorities. As a political actor, 'the public' stood in a responsive relationship to politicians and state institutions on the one hand, and mass media on the other.

These often implicitly held images have been pervasive in spite of the fact that most serious sociologists (from Simmel and Dewey to Habermas, Bourdieu and Giddens) would frequently warn against the fallacies of such amorphous and homogenizing views of 'the public' and 'the public sphere'. And attempts such as those of Dewey and Habermas to make citizens less responsive and inert, and more proactive and influential in the political process, often got no further than proposals for more structured, well-informed, rational debate in 'the public sphere'.

We now realize that this public sphere is profoundly fragmented. I suppose it always was fragmented, but the mainstream sociological imagination privileged artificial homogenization over actual fragmentation. In the online-offline nexus, we definitively must abandon this construct of a single and unified public sphere made

2. The debate between Lippman (1922) and Dewey (1927) can serve as an example. The debate structured two major lines of argument regarding the connection between politics, media as information providers, and the public, a pessimistic line and an optimistic one, respectively. These lines provide an accurate heuristics for following $20^{\text {th }}$ century debates on the role and place of media in western democracies. Obviously, the views of e.g. Horkheimer \& Adorno (1947) and Postman (1985) - to name just those influential voices - also fit into the same mold. 
up of 'the masses' and manipulated by the 'mass media'. In the new hybrid media system in which old and new media constantly interact, algorithms do not target 'the masses', they target a multitude of highly specific audiences ('micro-populations' in the terms of MALY; VARIS, 2016) in what has become known as 'micromarketing' or 'niche marketing'. 'Mass' effects - think of the Brexit referendum and the election of Donald Trump as US president - are achieved by establishing loose, temporal and unstable coalitions between such micro-audiences. 'Mass' media in the $20^{\text {th }}$ century sense of the term (currently called 'mainstream media' or MSM) now also operate on the logic of micromarketing algorithms and in close synergy with online platforms and social media. They are no longer hegemonic in the 'public sphere' in the ways that led, e.g., Lipmann and Dewey to their reflections on the role of media in a democracy. And manufacturing consent in the way Herman and Chomsky understood it now demands intense and coordinated activity on far more and more diverse media platforms, operating in a fragmented field of media content production and circulation.

I'm afraid that the public sphere - a phrase that has been used a zillion times in social and political analysis - has become practically meaningless. And the propaganda models that were so predominant in public discourse analysis also need to be fundamentally revisited, because two of their key elements have been dislodged: mass media in the $20^{\text {th }}$ century sense, and the public sphere in the modernist sense outlined above. They have been replaced by complex systems of communication aimed at micromarketing.

As for rational debate within this public sphere - the duty of democratic citizens and the task of their mass media in the eyes of generations of social and political theorists - the same conclusion seems compelling. If propaganda models need to be replaced by micromarketing models of public communication, the features of marketing need to be taken serious. I shall now recite the commonplace features of such marketing practices: they are irrational, aestheticized and emotive. But let's note with some emphasis that these features were already attributed to Nazi politics by Walter Benjamin in 1936. It is safe to assume that aesthetics has never been absent from the political sphere, and that it may even be one of its key features in retrospect. Let us equally note that these features, while not rational, are epistemic nonetheless: they organize modes of knowledge construction, of argumentation and persuasion just as effectively as rational, fact-based practices (cf. BLOMMAERT, 2018a; PROCHAZCA; BLOMMAERT, 2019). Meaning is as much an effect of discursive shape as it is of discursive content, as Dell Hymes (1996) famously reminded us. Clickbait simply reaffirms this, as does the prominence 
of 'fake news' and 'alternative facts' (or outright lies) in contemporary political campaigns.

The implications of all of this are clear, and I will quickly sketch three major ones. All three are related to how we imagine the democratic system as an actually existing contemporary mode of organization of the political field.

First, we need to abandon the (cherished) idea of modern democracy as a rational system of decision- making, revolving around 'the truth' and with this 'truth' as the point around which consensus (and coalitions) can be formed. Few issues are presently as controversial as 'the truth', and commentators sometimes refer to our times as the 'post-truth' era. In actual practice, it is best to approach democratic decision-making as a 'mixed method' thing in which rational practices are just one element, and not always the prevailing one.

Second, we also need to distance ourselves from traditional views of contemporary democratic decision- making as carried along by relatively stable (and sociologically pre-defined) majorities engaged in rational debate with equally relatively stable minorities. And third, we need to distance ourselves from the idea of 'public opinion' as a reliable indicator of such majority-minority divisions.

Both elements - the majority-minority divisions and the notion of public opinion - too often operate as unchallenged a priori assumptions in analysis. In times of micromarketing and fragmented audiences, such assumptions need to be empirically demonstrated if we wish to get a precise view of the actual political process and the role of discursive action in that process. If we take these three implications on board, we are facing a more general one. An adequate understanding of the contemporary political system requires another sociological imagination (cf. BLOMMAERT, 2018b), for the one we tend to carry along in our analyses reflects a political process that might have been accurate in the $20^{\text {th }}$ century, but no longer corresponds to the field that prevails today.

\section{REVISITING MODELS OF COMMUNICATION}

I can now turn to the second reflection. It is, obviously, connected to the previous one and can be seen as a more specific extension of it of particular immediacy for discourse analysts. Here, too, my remarks address deep and influential assumptions often implicitly articulated in analysis - assumptions about the model of communication underlying analysis. ${ }^{3}$

3. The following paragraphs are adapted from Blommaert (2019). 
I shall start from something which all of us learned during our first year of language studies: Saussure's sender-receiver model of communication (SAUSSURE, 1960, p. 27). (See Figure 1)

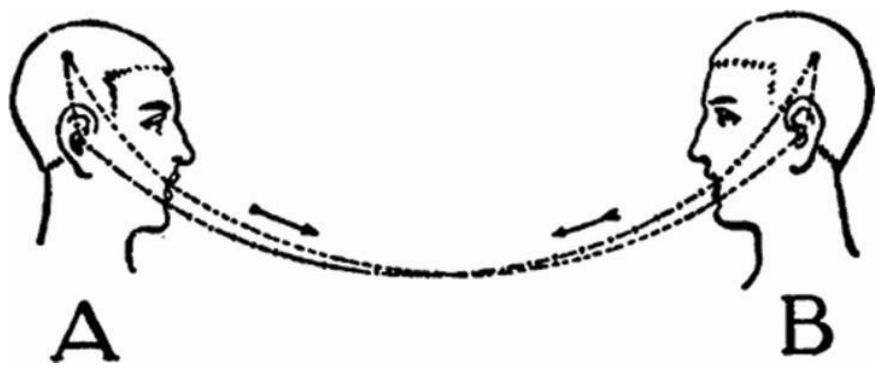

Figure 1. Saussure's model of communication

We see two (male) individual humans, $\mathrm{A}$ and $\mathrm{B}_{i} \mathrm{~A}$ produces an utterance originating in his brain and transmits it through his mouth to the ears of $\mathrm{B}$, who processes it in his brain and responds to it. Both $\mathrm{A}$ and $\mathrm{B}$ perform these acts synchronically (in a real moment of interaction) and symmetrically: the acts of A and B are identical in Saussure's model. All of this is very well-known, but we should remind ourselves that this simply dyadic sender-receiver model is, to a large extent, still the default model for imagining communication at large, and thus serves as the backdrop for communication theorizing. Note: it is individual, buman, spoken, linear, synchronic and direct within a clear sender-receiver relationship.

With this in mind, let us turn to the actual contemporary forms of communication in the post-digital era. Here is the main structure of communication on Twitter. (See figure 2) 


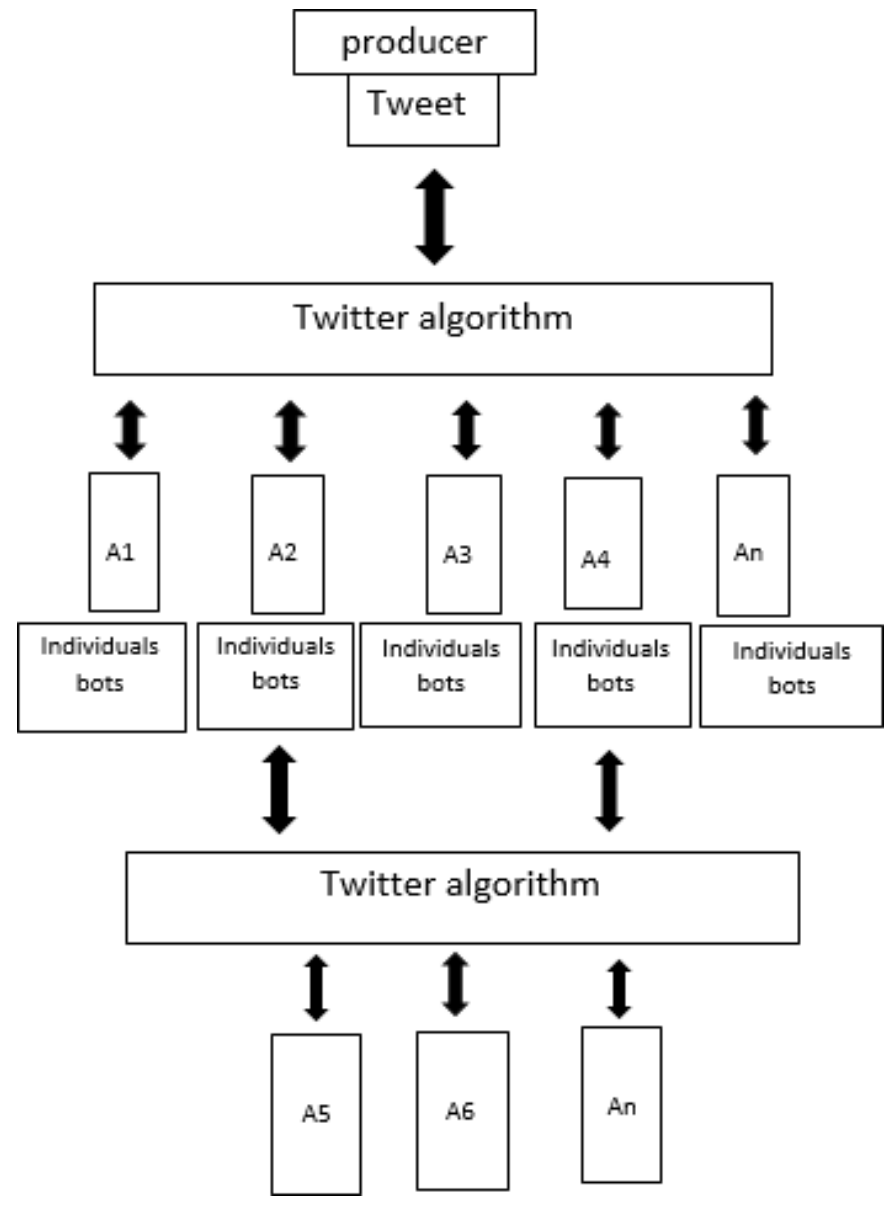

Figure 2. Communication structure on Twitter

We see a very different and much more complex structure of communication here. The tweet, produced by someone (e.g. president Trump), is sent to an algorithm - a nonhuman 'receiver', if you wish - through which artificial intelligence operations forward it to numerous specific audiences (A 1, 2, ...n in figure 3), whose responses are fed back, as data, to the algorithm and thence to the sender of the tweet in nonstop sequences of indirect, mediated interaction. Parts of these audiences can relay their own uptake of the tweet (via the Twitter algorithm) to secondary audiences (A 5, $6 \ldots \mathrm{n}$ in the scheme), who can do the same - and so on, enabling a tweet to reach audiences not initially accessible, both immediately after the moment of tweeting and much later. The audiences (also often called 'bubbles') are constructed by the algorithms out of users' data-yielding profiles, and they are 
selected on the basis of a range of 'data points' including topic keywords, hashtags and histories of prior interactions. The audiences consist of individuals, sure $;$ but in the case of Trump and many other high-profile accounts also of bots - computer programs behaving like 'normal' Twitter users and generating specific forms of response such as liking and retweeting and sometimes dramatically increasing the volume of traffic for tweets.

What we need to take along here is this:

(1) There is no linear, symmetrical and direct sender-receiver structure on Twitter, because the platform itself provides an algorithmic mediator for all and any interaction.

(2) The participants are, consequently, not all human, as very crucial parts of the communication structure are controlled by automated AI technologies.

(3) As an effect of these algorithmic mediations, there is not a single 'audience' (or 'public') in the structure of communication, but a fragmented complex of 'niched' audiences often with incompatible interests or political orientations.

(4) There is also not a single producer of discourse here: political discourse is produced and circulated by all actors within this model, humans as well as nonhumans.

(5) The entire system is permanently in motion, with constant interactional conversions of actions performed by (human and nonhuman) participants into data further shaping and regulating the effects of the actions (cf. MALY, 2018).

(6) These actions are indirect, i.e. mediated by technologies as well as by the uptake and feedback actions of (unknown and unintended) audiences.

(7) They are also not synchronic but spread over variable spans of time. Actions can be performed months or years after the original moment of tweeting, because of the archiving capacity of online platforms.

(8) Finally, we are observing scripted communication here, not spoken communication. We are in a field of literacy here; this field is extraordinarily diverse and involves, for instance, different kinds of platforms on which literacy practices are performed. The conversion of all actual online practices into data, to be used in $\mathrm{AI}$ and in micromarketing, must be included into this.

These are empirical observations, and specific ones. But even if we would prefer to minimalize their potential for extrapolation and generalization (something I would not encourage), these observations do not in any way fit into Saussure's old model of communication, nor can they be made to fit into it. The model is simply 
irrelevant as a tool to generalize the actual modes of communication we face when looking at these types of examples.

Models of communication in the post-digital era need to be models in which the characteristics of the online-offline nexus are absorbed as a reality affecting the phenomenology of communication in the most profound sense. This is, I think, a matter of realism in scientific practice: the frameworks for generalization we use need to be grounded in empirical analytical insights reflecting the 'is' of communication, not its 'ought'. More concretely, political discourse analysis needs to be re-footed on the basis of the new kinds of communicative economies (including resources, actors and relationships between actors) we observe and inhabit.

\section{A POLYCENTRIC WORLD OF COMMUNICATION}

The latter remark takes us back to what was said earlier: political communication in post-digital environments involves a multitude of actors, some of whom are human and some non-human, and all of whom operate both as producers and receivers of political messages. The idea that political discourse is the discourse of professional politicians alone, or even primarily, is an anachronism. True, politicians often provide the 'input' for the complex communication processes outlined in the previous section; but they do not determine its effects, intensity or scale of circulation - things performed by the multiple audiences (including bots) in interaction with platform algorithms. Here, too, we can observe the limits and inadequacies of the older propaganda models: demonstrating that 'the public' is 'influenced' by politicians' political messages - in which the politician (and his/ her messages) is the key actor - nowadays requires a very intricate analysis of 'who does what'. Outcomes of such analyses might suggest that parts of the public influence other parts of that public, or more precisely: they might suggest that not politicians, but specific audiences influence other audiences, and that this is achieved by means of a multitude of processes of re-entextualization (SILVERSTEIN, 1996).

Entextualization refers to the process by means of which discourses are successively or simultaneously decontextualized and metadiscursively recontextualized, so that they become a new discourse associated to a new context and accompanied by a particular metadiscourse which provides a sort of 'preferred reading' for the discourse. This key concept helps us understand that 'virality' the large-scale distribution of messages by means of online 'copy' practices such as reposts, retweets and so forth - is not, in fact, a series of repetitions of 'the same' message, but a series of re-entextualizations (cf VARIS; BLOMMAERT, 2015). 
In such re-entextualizations, the message of a politician is taken by an audience member - it is appropriated, if you wish - and inserted into an entirely new act of communication involving a new producer (the audience member) and addressees (the audience member's own network of online 'friends' or 'followers') in a new kind of interaction, with the algorithms mediating this new and more complicated process, the 'data' of which are fed back to the politicians' original act of communication, even if the characteristics of the new act of communication diverge strongly from those of the original ('input') act.

Concretely, imagine that I retweet a tweet launched by president Trump. I am not one of Mr. Trump's supporters; in fact, I'm highly critical of his presidency and I became a 'follower' of Mr. Trump's Twitter account because it offers me plenty of powerful arguments to be critical. My retweet would reach a network of people broadly aligned with my views (my bubble), and it is likely that this specific audience of mine will understand my retweet as a critical comment on $\mathrm{Mr}$. Trump, not as an act of support for him and his views. My retweet, in short, is a reentextualization that conveys a negative message on Mr. Trump, not the positive one articulated in lots of other retweets (and preferred, one dares to venture, by $\mathrm{Mr}$. Trump himself). But the Twitter algorithm will add my retweet to the total 'virality' of Mr. Trump's original tweet, allowing him and his supporters to interpret my act as a form of popular support for (and possibly even agreement with) Mr. Trump's message.

We observe polycentricity here: the circulation of political messages in the online-offline nexus does not, in any way, allow us to attach one single interpretation to that meaning. Sixty thousand retweets of Mr. Trump's message cannot be read as sixty thousand acts of support and agreement - widely divergent interpretations will be included in what looks like simple repetitions of the same message. Observe (but I can only mention this in passing here) that new interpretations can be added much later, given the archival capacity of the Web: the tweets can be invoked as evidence in litigation, for example, or as evidence of contradictions or unconventional policy shifts by the president. Online messages inevitably end up in a system of communication in which the actually communicated meaning of such messages is open to very profound indexical re-orderings and, hence, of very different readings depending on the kinds of appropriations mentioned above.

Explanations for this can be found in the Twitter model of communication I sketched above: we are facing nonlinear, asymmetrical and non-synchronic acts of communication here, involving different 'indexical centers' (cf. BLOMMAERT, 2005). In the example I gave, I am such an indexical center for my own Twitter 
audience, and the indexical order I apply to Mr. Trump's message will be very different from that attributed to it by supporters of the president, who represent another range of indexical centers. The algorithms, of course, are also very powerful indexical centers in the entire process. In each instance, entirely different sets of social, cultural and moral norms will be applied to the messages, and what such messages actually do in communication will depend on such widely divergent norms (cf. BLOMMAERT, 2019).

This feature of political (and other) communication in the post-digital era is yet another argument against simple propaganda models. Politicians quite often understand the numbers of retweets as well as the numbers of 'followers' or 'friends' of their social media accounts as evidence of the level of popular (often called 'democratic') support they command - an anachronistic reading grounded in the propaganda model and very much at odds with the actual facts of communication, uptake and effect of their messages. As said earlier, there is no way in which we can see online audiences as yet another embodiment of 'the masses' in the $20^{\text {th }}$ century, modernist sense of that term.

\section{GOOD AND BAD NEWS FOR DISCOURSE ANALYSTS}

The last reflection has a clear implication: politicians need to be aware of the widely divergent meanings that their messages allow, and need to spend a great deal of care for the actual forms of communication they engage in. Advanced bigdata based micromarketing assists them in the process, but messages targeting specific audiences still have the capacity to spill over into unintended audiences and generate a powerful negative backlash that way. Remember that the ultimate aim is to construct (temporary and ephemeral, but real) coalitions of different audiences; negative backlash from unintended audiences can render the construction of such coalitions more difficult or impossible.

All of this is good news for political discourse analysts. It is also bad news. The good news is that the increased attention for actual forms of political communication creates a demand for nonstop, intensive and sophisticated discourse analysis. I did my PhD in 1989 on Swahili political discourse in Tanzania. In those days, our material consisted of a finite body of texts - speeches given and texts written by politicians, possibly complemented by mass-media reports of such speeches and texts. Political discourse analysis today is much more exciting, for accurate analysis now involves the capacity to change analytical strategies whenever the field and its constituent elements change - and this is now a permanent process. 
This, of course, can also be seen as bad news. The toolkit with which I engaged with my Tanzanian texts in the 1980s was outstanding in its usefulness and clarity - we had standard 'recipes', so to speak, for doing the work of political discourse analysis. We no longer have the comfort of such clarity, for political discourse analysis, as just mentioned, now includes perpetual adjustment of perennially unfinished tools and tactics to adequately address a moving target. This challenge is theoretical, methodological, but also practical. Political discourse analysis is of crucial importance if we want to understand the complexities of the societies we inhabit. So there is not just a demand for such analysis but a need to continue providing it. The fact that this work becomes more difficult and more demanding should not deter us - the answer to it is a key scientific ambition called 'innovation'.

\section{REFERENCES}

ARNAUT, Karel; KARREBAEK, Martha; SPOTTI, Massimiliano. (2017). Engaging superdiversity: The poesis- infrastructures nexus and language practices in combinatorial spaces. In: Karel Arnaut, Jan Blommaert, Martha Karrebaek \& Massimiliano Spotti (eds.) Engaging Superdiversity: Recombining Spaces, Times and Language Practices: 3-24. Bristol: Multilingual Matters.

BENJAMIN, Walter. (1936 [2002]). The work of art in the age of its technological reproducibility. In: Walter Benjamin, Selected Essays, Volume 3: 1935-1938 (eds. Howard Eiland \& Michael Jennings). Cambridge MA: Belknapp Press of Harvard University Press.

BLOMMAERT, Jan. (2005). Discourse: A Critical Introduction. Cambridge: Cambridge University Press.

BLOMMAERT, Jan. (2018a). Trump's tweetopoetics. Tilburg Papers in Culture Studies, paper 203. Downloaded from https://www.tilburguniversity.edu/research/institutes-andresearch- groups/babylon/tpcs

BLOMMAERT, Jan. (2018b). Durkbeim and the Internet: On Sociolinguistics and the Sociological Imagination. London: Bloomsbury.

BLOMMAERT, Jan. (2019). Sociolinguistic restratification in the online-offline nexus: Trump's viral errors. Tilburg papers in Culture Studies, paper 234. Downloaded from https://www.tilburguniversity.edu/research/institutes-and-research-groups/ babylon/tpcs 
CRAMER, Florian. (2014). What is 'post-digital'? A Peer-Reviewed Journal About Post-Digital Research 3/1: 10-24. https://monoskop.org/File:A_Peer-Reviewed_Journal_About_ Post-Digital_Research_2014.pdf

DEWEY, John. (1927). The Public and Its Problems. New York: Holt. Fairclough, Norman (1989) Language and Power. London: Longman.

HERMAN, Edward; CHOMSKY, Noam. (1988). Manufacturing Consent: The Political Economy of the Mass Media. New York: Pantheon.

HORKHEIMER, Max; ADORNO, Theodor. (1947 [2002]). Dialectic of Enligbtenment. Stanford: Stanford University Press.

HYMES, Dell. (1996). Ethnography, Linguistics, Narrative Inequality: Toward an Understanding of Voice > London: Taylor \& Francis.

LIPPMAN, Walter. (1922). Public Opinion. New York: Harcourt.

Maly, Ico (2018) Populism as a mediatized communicative relation: The birth of algorithmic populism. Tilburg Papers in Culture Studies, paper 213. Downloaded from https://www. tilburguniversity.edu/research/institutes-and-research-groups/babylon/tpcs

MALY, Ico; VARIS, Piia. (2016). The $21^{\text {st }}$ century hipster: On micro-populations in times of superdiversity. European Journal of Cultural Studies 19/6: 637-653. https://doi. org/10.1177/1367549415597920

POSTMAN, Neil. (1985). Amusing Ourselves to Deatb: Public Discourse in the Age of Show Business. New York: Viking.

PROCHZKA, Ondrej; BLOMMAERT, Jan. (2019). Ergoic framing in New Right online groups: Q, the MAGA kid, and the deep state theory. Tilburg Papers in Culture Studies, paper 224. Downloaded from https://www.tilburguniversity.edu/research/institutesand-research-groups/babylon/tpcs

SAUSSURE, Ferdinand de. (1960). Cours de Linguistique Générale (eds. Charles Bally \& Albert Sechehaye). Paris: Payot.

SILVERSTEIN, Michael. (1996). The secret life of texts. In Michael Silverstein \& Greg Urban (eds.) Natural Histories of Discourse: 81-105. Chicago: University of Chicago Press. 
VARIS, Piia; BLOMMAERT, Jan. (2015). Conviviality and collectives on social media: Virality, memes, and new social structures. Multilingual Margins 2/1: 31-45.

Recebido: $31 / 01 / 2020$

Aceito: 8/04/2020

Publicado: 8/04/2020 